
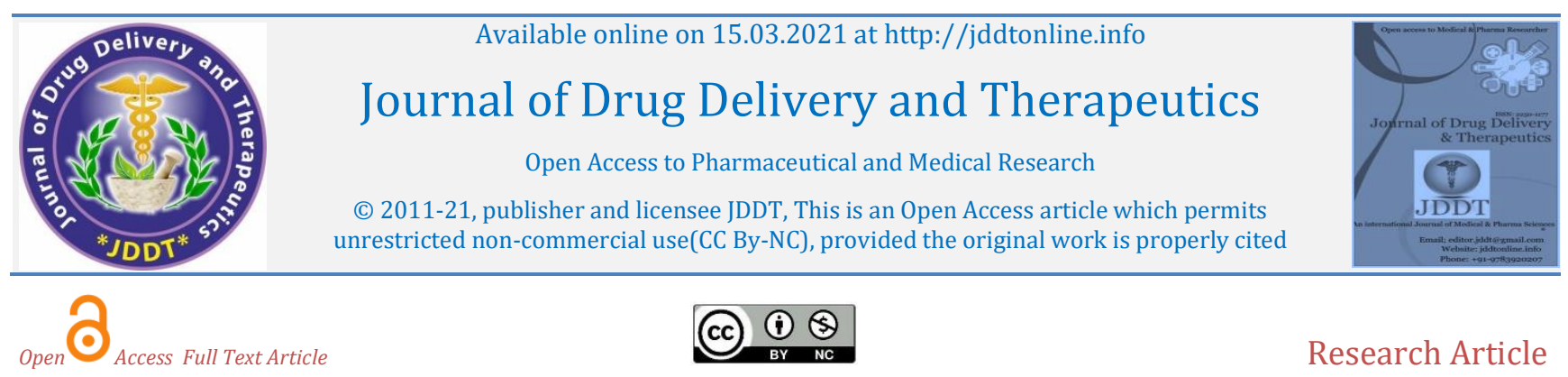

Research Article

\title{
Qualitative Phytochemical Screening of Selected Medicinal Plants
}

\author{
Mohan E1, Suriya S2, Shanmugam S1*, Rajendran $\mathrm{K}^{1}$ \\ ${ }^{1}$ Post Graduate and Research Department of Botany, Thiagarajar College, Teppakulam, Madurai - 625009, Tamil Nadu, India \\ ${ }^{2}$ Department of Botany, Yadava College, Tiruppalai, Madurai - 625014, Tamil Nadu, India
}

\section{Article Info:

Article History:
Received 11 Jan 2021;
Accepted 08 March 2021;
Available online 15 March 2021

Cite this article as:

Mohan E, Suriya S, Shanmugam S, Rajendran K, Qualitative Phytochemical Screening of Selected Medicinal Plants, Journal of Drug Delivery and Therapeutics. 2021; 11(2):141-144 DOI: http://dx.doi.org/10.22270/jddt.v11i2.4609

\section{*Address for Correspondence:}

S. Shanmugam, Research Scholar, Post Graduate and Research Department of Botany, Thiagarajar College, 139-140, Kamarajar Road, Teppakulam, Madurai - 625009, Tamil Nadu, India.

\section{Abstract}

Phytochemicals have great potency as therapeutic agents. There is continuous and urgent need to discover new therapeutic compounds with diverse chemical structures and novel mechanism of action because there has been an alarming increase in the incidence of new and re-emerging infectious diseases. Hence, the present investigation was carried out to assess the phytoconstituents of leaf extracts of four different medicinal plants viz. Acorus calamus, Senna alata, Solanum torvum and Solanum trilobatum. The leaves of four plants were collected from their wild habitats, washed, air dried and then powdered. The solvent extracts of the respective leaves were prepared using Soxhlet apparatus with acetone, ethanol and petroleum ether. The extracts were subjected to preliminary phytochemical analyses as per standard procedures. The results showed that alkaloids were present in all the four plants analyzed and all the three solvents extracted. Meanwhile, carbohydrates and proteins were absent in the same. It was also indicated that the ethanol extract of Solanum trilobatum leaf showed the presence of 7 compounds among 9 phytochemicals analyzed. The result of this study is encouraging further quantitative estimation and the need for clinical studies to determine the potential effectiveness of particular phytochemical in vivo.

Keywords: Preliminary phytochemical analyses, Acorus calamus, Senna alata, Solanum torvum and Solanum trilobatum.

\section{INTRODUCTION}

Plant-derived substances have recently become of great interest owing to their versatile applications. Medicinal plants are a group of species that accumulate different active principles, useful in treating various human or animal diseases. They are the richest bio-resource of drugs of traditional systems of medicine, modern medicines, nutraceuticals, food supplements, folk medicines, pharmaceutical intermediates and chemical entities for synthetic drugs ${ }^{1}$.

Phytochemicals are naturally occurring in different parts of the medicinal plants that have defense mechanism and protect from various diseases 2 . The medicinal plants are useful for healing as well as for curing of human diseases because of the presence of phytochemical constituents which produce definite physiological action on the human body and these bioactive substances include alkaloids, carbohydrates, terpenoids, steroids, flavonoids, tannins, etc. 3 .

Plants with prospective medicinal activity have recently come to the attention of scientists and researchers because of their bioactive potential. Preliminary screening of phytochemicals is a valuable step in the detection of the bioactive principles present in medicinal plants and subsequently may lead to drug discovery and development. Due to the significance in this above perspective, such preliminary phytochemical screening of plants is the need of the hour in order to discover and develop novel therapeutic agents with improved value. Thus, the present study was aimed to assess the various phytoconstituents present in the leaf extracts of selected medicinal plants such as Acorus calamus, Senna alata, Solanum torvum and Solanum trilobatum and these plants were selected based on their ethnomedicinal importance ${ }^{4-7}$.

\section{MATERIALS AND METHODS}

\subsection{Plant sample collection}

The healthy leaves of Acorus calamus L. (Acoraceae Vasambu), Senna alata (L.) Roxb. (Fabaceae - Seemaiagathi), Solanum torvum Sw. (Solanaceae - Sundaikkaai) and Solanum trilobatum L. (Solanaceae - Thoodhuvalai) were collected from their natural habitats in Kathakinaru village (9.9865 $\mathrm{N}$ latitude and 78.1717ㅇ E longitude) of Madurai district in Tamil Nadu, India, and brought to the laboratory. The leaves were washed separately with tap water and shade dried at room temperature to attain constant weight. The air dried samples were powdered in an electric blender 
and stored in plastic bags for further analysis. All the plants were botanically confirmed and authenticated as per APG IV classification ${ }^{8}$.

\subsection{Preparation of plant extract}

The dried powder material was extracted sequentially in three different solvents viz., acetone, ethanol and petroleum ether. $15 \mathrm{~g}$ of the dried and powdered plant material were extracted with $150 \mathrm{ml}$ of ethanol, acetone and petroleum ether using soxhlet apparatus for 6-8 hours at a temperature not exceeding the boiling point of the solvents. The obtained crude extracts were filtered by using Whatman No. 1 filter paper and then concentrated under vacuum at $40^{\circ} \mathrm{C}$ by using a rotary evaporator and later stored at $4^{\circ} \mathrm{C}$ for further use.

\subsection{Qualitative phytochemical analysis}

Preliminary phytochemical analyses were carried out on the leaf extracts of Acorus calamus, Senna alata, Solanum torvum and Solanum trilobatum in order to determine the presence of different phytochemicals like alkaloids, carbohydrates, flavonoids, glycosides, phenols, phytosterols, proteins, saponins and tannins by subjecting the following standard procedures for respective phytochemical. Mayer's test for alkaloids 9, Fehling's test for carbohydrates 10, Alkaline reagent test for flavonoids 11, Keller-Killiani test for glycosides 12, Ferric chloride test for both phenols and tannins 13 , Salkowski test for phytosterols ${ }^{12}$, Biuret test for protein 14 and Foam test for saponins ${ }^{13}$. The qualitative results were expressed as (+) for the presence and (-) for the absence of phytochemical.

\section{RESULT AND DISCUSSION}

The results regarding the phytochemical screening of Acorus calamus leaf, alkaloids, glycosides, phytosterols and saponins were found to be present in acetone extract, alkaloids and saponins were present in ethanol extract, and alkaloids, flavonoids, phytosterols and saponins in petroleum ether extract. All the three extracts showed the presence of alkaloids and saponins, and absence of carbohydrates, phenols, proteins and tannins. Most number of phytochemicals (4) were found to be present in both acetone and petroleum ether extract than that of ethanol (Table 1).

Table 1: Preliminary phytochemical screening of Acorus calamus leaf

\begin{tabular}{|l|c|c|c|}
\hline \multirow{2}{*}{ Phytochemical } & \multicolumn{3}{|l|}{ Solvent extract } \\
\cline { 2 - 4 } & Acetone & Ethanol & $\begin{array}{c}\text { Petroleum } \\
\text { ether }\end{array}$ \\
\hline Alkaloids & + & + & + \\
\hline Carbohydrates & - & - & - \\
\hline Flavonoids & - & - & + \\
\hline Glycosides & + & - & - \\
\hline Phenols & - & - & - \\
\hline Phytosterols & + & - & + \\
\hline Proteins & - & - & - \\
\hline Saponins & + & + & + \\
\hline Tannins & - & - & - \\
\hline
\end{tabular}

In case of Senna alata leaf revealed that acetone extract covered the presence of alkaloids and glycosides, ethanol extract showed the presence of alkaloids, glycosides and tannins, whereas the petroleum ether extract exposed the presence of alkaloids and tannins. In all the three extracts, alkaloids were present and carbohydrates, flavonoids, phenols, phytosterols, proteins and saponins were found to be absent. Of all the phytoconstituents analyzed, most of the compounds (3) were detected in ethanol extract than others (Table 2).

Table 2: Preliminary phytochemical screening of Senna alata leaf

\begin{tabular}{|l|c|c|c|}
\hline \multirow{2}{*}{ Phytochemical } & \multicolumn{3}{|l|}{ Solvent extract } \\
\cline { 2 - 4 } & Acetone & Ethanol & $\begin{array}{c}\text { Petroleum } \\
\text { ether }\end{array}$ \\
\hline Alkaloids & + & + & + \\
\hline Carbohydrates & - & - & - \\
\hline Flavonoids & - & - & - \\
\hline Glycosides & + & + & - \\
\hline Phenols & - & - & - \\
\hline Phytosterols & - & - & - \\
\hline Proteins & - & - & - \\
\hline Saponins & - & - & - \\
\hline Tannins & - & + & + \\
\hline
\end{tabular}

In Solanum torvum leaf extracted with acetone, alkaloids, phytosterols, saponins and tannins were found to be present. The ethanol extract of the same showed the presence of alkaloids, flavonoids, phytosterols and saponins, and petroleum ether extract revealed the presence of alkaloids, glycosides, phytosterols and saponins. Alkaloids, phytosterols and flavonoids were found to be present in all the three solvents and carbohydrates, phenols and proteins were absent. Among the phytochemicals tested, all the three solvents exposed 4 compounds each (Table 3 ).

Table 3: Preliminary phytochemical screening of Solanum torvum leaf

\begin{tabular}{|l|c|c|c|}
\hline \multirow{2}{*}{ Phytochemical } & \multicolumn{3}{|l|}{ Solvent extract } \\
\cline { 2 - 4 } & Acetone & Ethanol & $\begin{array}{c}\text { Petroleum } \\
\text { ether }\end{array}$ \\
\hline Alkaloids & + & + & + \\
\hline Carbohydrates & - & - & - \\
\hline Flavonoids & - & + & - \\
\hline Glycosides & - & - & + \\
\hline Phenols & - & - & - \\
\hline Phytosterols & + & + & + \\
\hline Proteins & - & - & - \\
\hline Saponins & + & + & + \\
\hline Tannins & + & - & - \\
\hline
\end{tabular}


The results of preliminary phytochemical screening of Solanum trilobatum leaf indicated that acetone extract exposed the presence of alkaloids, flavonoids, glycosides, phenols, saponins and tannins. However, ethanol extract revealed the presence of alkaloids, flavonoids, glycosides, phenols, phytosterols, saponins and tannins, whereas the petroleum ether extract highlighted the presence of alkaloids, flavonoids, phenols, saponins and tannins Alkaloids, flavonoids, phenols, saponins and tannins were detected in all the three solvent, on other hand carbohydrates and proteins were non-detected. More number of compounds (7) were found to be present in ethanol extract than other two solvents (table 4)

Overall findings of the present study highlighted that alkaloids were present in all the four plants analyzed and all the three solvents extracted. Meanwhile, carbohydrates and proteins were absent in the same. Regarding the number of compounds detected, the ethanol extract of Solanum trilobatum showed the presence of 7 phytochemicals as highest, and acetone, petroleum ether extracts of Senna alata and ethanol extract of Acorus calamus revealed the presence of 2 compounds each as least (Fig 1).
Table 4: Preliminary phytochemical screening of Solanum trilobatum leaf

\begin{tabular}{|l|c|c|c|}
\hline \multirow{2}{*}{ Phytochemical } & \multicolumn{3}{|l|}{ Solvent extract } \\
\cline { 2 - 4 } & Acetone & Ethanol & $\begin{array}{c}\text { Petroleum } \\
\text { ether }\end{array}$ \\
\hline Alkaloids & + & + & + \\
\hline Carbohydrates & - & - & - \\
\hline Flavonoids & + & + & + \\
\hline Glycosides & + & + & - \\
\hline Phenols & + & + & + \\
\hline Phytosterols & - & + & - \\
\hline Proteins & - & - & - \\
\hline Saponins & + & + & + \\
\hline Tannins & + & + & + \\
\hline
\end{tabular}

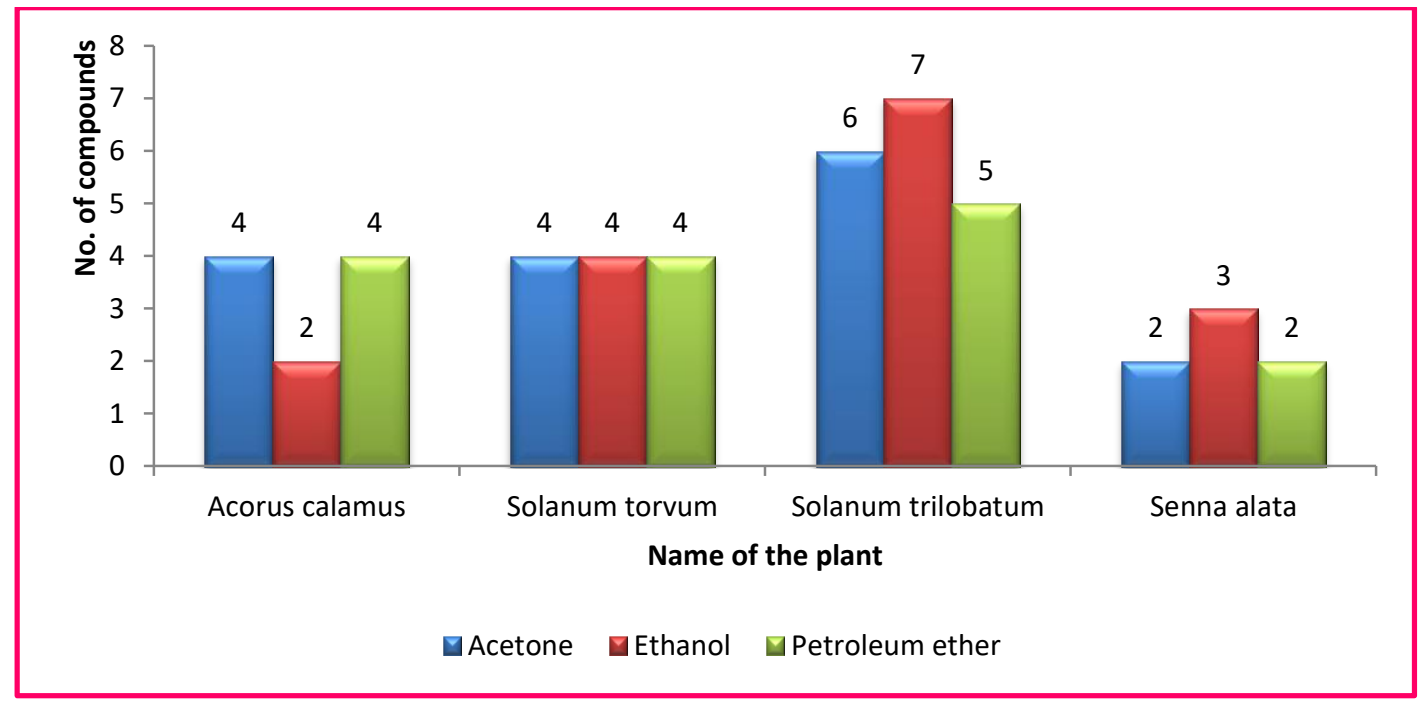

Figure 1: Number of compounds detected in respective plants and solvent extracts

From the findings of current research work, it was also clearly known that most of phytoconstituents were detected in ethanol extract than that of acetone and petroleum ether extracts. This can be attributable to the higher solubility of the phytocompounds of plant material in ethanol than other solvents. The recovery of phytochemical from plant sample could also be influenced by dielectric constant, chemical structure of solvents used, and as well as chemical properties of phytochemicals ${ }^{15}$.

The preliminary phytochemical screening of the four medicinal plants selected for this present study showed that they own their phytoconstituents and such phytochemicals have several important biological activities. It was reported that alkaloids have the pharmacological activities like antimicrobial 16, antiarrhythmic, analgesic 17 and antihyperglycemic 18 activities. It was known that flavonoids possesses alpha-glucosidase activity ${ }^{19}$, antioxidant activity 20 and anti-inflammatory activity 21 .

Phenolic compounds are also known for their antiinflammatory 22,23, antimicrobial $24-26$, and antioxidant 27,28 effects. Saponins exhibit a variety of biological activities like anti-inflammatory ${ }^{29}$, hypocholesterolemic 30 and immunestimulating ${ }^{31}$, insecticidal and antimicrobial properties ${ }^{32}$, antidiabetic 33, cytotoxic 34 and central nervous system activities 35,36 . Tannins have been reported to have various physiological effects like anti-irritant, antiparasitic effects ${ }^{37}$. These research evidences strongly justify the medicinal usage of leaves of Acorus calamus, Senna alata, Solanum torvum and Solanum trilobatum as they contained the above mentioned biologically important phytochemicals detected by the present study.

\section{CONCLUSION}

Further quantitative and chromatographic studies should be carried out on the phytochemical compounds present in Acorus calamus, Senna alata, Solanum torvum and Solanum trilobatum to isolate, identify, characterize and elucidate the structure of the bioactive compounds. There may be a chance to discover a new compound which leads to the birth of new drug. Biological efficacies of the isolated compounds should also be tested using animal models. 


\section{CONFLICT OF INTEREST}

The authors have declared that there is no conflict of interest.

\section{REFERENCES}

1. Ncube NS, Afolayan AJ \& Okoh AI. Assessment techniques of antimicrobial properties of natural compounds of plant origin: current methods and future trends. African Journal of Biotechnology 2008; 7(12):1797-1806.

2. Krishnaiah D, Sarbatly R \& Bono A. Phytochemical antioxidants for health and medicine: A move towards nature. Biotechnology and Molecular Biology Reviews, 2007; 1:97-104.

3. Nostro A, Germanò MP, D'angelo V, Marino A \& Cannatelli MA. Extraction methods and bioautography for evaluation of medicinal plant antimicrobial activity. Letters of Applied Microbiology, 2000; 30: 379-384.

4. Shanmugam S, Rajagopal V \& Rajendran K. Multipurpose usable plants in Thalaiyanai hills of Tirunelveli forest division in southern part of Western Ghats. Journal of Non-Timber Forest Products, 2007; 14(4):297-306.

5. Shanmugam S, Rajendran K \& Suresh K. Traditional uses of medicinal plants among the rural people in Sivagangai district of Tamil Nadu, Southern India. Asian Pacific Journal of Tropical Biomedicine, 2012; 2:S429-S434.

6. Shanmugam S, Balamurugan S, Pandiselvam P \& Rajendran K. Medicinal plants used by people of Thiruppuvanam and its surrounding areas of Sivagangai district in Tamil Nadu, Southern India. Journal of Basic and Applied Biology, 2012; 6:39-45.

7. Shanmugam S, Sundari A, Muneeswaran S, Vasanth C, Jayakumararaj R \& Rajendran K. Ethnobotanical Indices on Medicinal Plants Used to Treat Poisonous Bites in Thiruppuvanam Region of Sivagangai District in Tamil Nadu, India. Journal of Drug Delivery and Therapeutics, 2020; 10(6s):31-36.

8. APG IV. An update of the Angiosperm Phylogeny Group classification for the orders and families of flowering plants. Botanical Journal of the Linnean Society, 2016; 181(1): 1-20.

9. Joshi CS, Sanmuga Priya E \& Mathela CS. Isolation and antiinflammatory activity of colchicinoids from Gloriosa superba seeds. Pharmaceutical Biology, 2010; 48(2):206-209.

10. Boxi M, Rajesh Y, Raja V, Praveen B \& Mangamma K. Extraction, phytochemical screening and in-vitro evaluation of anti-oxidant properties of Commicarpus chinesis (Aqueous leaf extract). International Journal of Pharmacy and Biological Sciences, 2010; 1:537-547.

11. Trease GE \& Evans WC. Pharmacognosy. In: Soundera WB. (Ed.), $4^{\text {th }}$ ed., New York Scientific Press, USA, 1996: 243-283.

12. Ayoola GA, Coker HAB, Adesegun SA, Adepoju-Bello A, Obaweya K, Ezennia EC \& Atangbayila TO. Phytochemical screening and antioxidant activities of some selected medicinal plants used for malaria therapy in Southwestern Nigeria. Tropical Journal of Pharmaceutical Research, 2008; 7(3):1019-1024.

13. Banso A \& Adeyemo S. Phytochemical screening and antimalarial assessment of Abutilon mauritianum, Bacopa monnifera and Datura stramonium. Biokemistri, 2006; 18:39-44.

14. Harborne JB. Phytochemical methods: A Guide to Modern Technique of Plant Analysis, Champman and Hall Publishers. London, 1998.

15. Felhi S, Daoud A, Hajlaoui H, Mnafgui K, Gharsallah N \& Kadri A. Solvent extraction effects on phytochemical constituents profiles, antioxidant and antimicrobial activities and functional group analysis of Ecballium elaterium seeds and peels fruits. Food Science and Technology (Campinas), 2017; 37(3):483-492.

16. Cushnie TP, Cushnie B \& Lamb AJ. Alkaloids: An overview of their antibacterial, antibiotic-enhancing and antivirulence activities. International Journal Antimicrobial Agents, 2014. 44(5):377-386.

17. Raymond SS, Jahr JS \& Pitchford JMW. The essence of Analgesia and Analgesics. Cambridge University Press, 2010: 82-90.
18. Qiu S, Sun H, Zhang AH, Xu HY, Yan GL, Han Y \& Wang XJ. Natural alkaloids: basic aspects, biological roles, and future perspectives. Chinese Journal of Natural Medicines, 2014; 12(6):401-406.

19. Geng P, Yang Y, Gao Z, Yu Y, Shi Q \& Bai G. Combined effect of total alkaloids from Feculae bombycis and natural flavonoids on diabetes. Journal of Pharmacy and Pharmacology, 2007; 59(8):1145-1150.

20. Gil MI, Ferreres F \& Tomas-Barberan FA. Effect of post-harvest storage and processing on the antioxidant constituents (flavonoids and vitamin C) of fresh-cut spinach. Journal of Agricultural and Food Chemistry, 1999; 47:2213-2217.

21. Panthong A, Kanjanapothi D, Tuntiwachwuttikul P, Pancharoen 0 \& Reutrakul V. Anti-inflammatory activity of flavonoids. Phytomedicine, 1994; 1:141-144.

22. Naczk M \& Shahidi F. Phenolics in cereals, fruits and vegetables: Occurrence, extraction and analysis. Journal of Pharmaceutical and Biomedical Analysis, 2006; 41:1523-1542.

23. Giftson JS, Jayanthi S \& Nalini N. Chemopreventive efficacy of gallic acid, an antioxidant and anticarcinogenic polyphenol, against 1, 2-dimethyl hydrazine induced rat colon carcinogenesis. Investigational New Drugs, 2010. 28:251-259.

24. Deng Y, Zhao Y, Padilla-Zakour O \& Yang G. Polyphenols, antioxidant and antimicrobial activities of leaf and bark extracts of Solidago canadensis L. Industrial Crops and Products, 2015; 74:803-809.

25. Popa VI. Wood bark as valuable raw material for compounds with biological activity. Celuloza Si Hârtie, 2015; 64:5-17.

26. Tanase C, Cosarca S, Toma F, Mare A, Man A, Miklos A, Imre S \& Boz I. Antibacterial activities of beech bark (Fagus sylvatica L.) polyphenolic extract. Environmental Engineering and Management Journal, 2018; 17: 877-884.

27. Subramanian R, Raj V, Manigandan K \& Elangovan $\mathrm{N}$ Antioxidant activity of hopeaphenol isolated from Shorea roxburghii stem bark extract. Journal of Taibah University for Science, 2015; 9:237-244.

28. Zaiter A, Becker L, Petit J, Zimmer D, Karam MC, Baudelaire É, Scher J \& Dicko A. Antioxidant and antiacetylcholinesterase activities of different granulometric classes of Salix alba L. bark powders. Powder Technology, 2016; 301:649-656.

29. Balandrin MF. Commercial utilization of plant-derived saponins: An overview of medicinal, pharmaceutical and industrial applications. In: Waller GR \& Yamasaki K. (Eds.), Saponins Used in Food and Agriculture, Plenum Press, New York, 1996:13-17.

30. Oakenfull D. Saponins in the treatment of hypercholesterolemia In: Spiller GA. (Ed.), Handbook of Lipids in Human Nutrition, CRC Press, Florida, US, 1996:34-36.

31. Thakur M, Melzig MF, Hendrik F \& Alexander W. Chemistry and pharmacology of saponins: special focus on cytotoxic properties. Journal of Botanics: Targets and Therapy, 2011; 1:19-29.

32. Chakraborty A \& Brantner HA. Antibacterial steroids, alkaloids from the stem bark of Holarrhena pubescens. Journal of Ethnopharmacology, 1999; 68:339-344.

33. Sharma RR. Preliminary phytochemical screening of some indigenous medicinal plants leaves extract in regulation of antidiabetic activity. Journal of Scientific Research and Reports, 2012; 2(3):307-310.

34. Mohammed AH, Nainna SZ, Yushau M, Salisu B, Adamu U \& Kabeer ZM. Antibacterial, cytotoxicity and GC-MS analysis of Psidium guajava extracts. Bayero Journal of Pure and Applied Sciences, 2017; 10(1):163-169.

35. Argal A \& Pathak AK. CNS activity of Calotropis gigantea roots. Journal of Ethnopharmacology, 2006; 106:142-145.

36. Amin Mir M, Sawhney SS \& Jassal MMS. Qualitative and quantitative analysis of phytochemicals of Taraxacum officinale. Wudpecker Journal of Pharmacy and Pharmacology, 2013; 2(1):01-05.

37. Naveen Prasad R, Viswanathan S, Renuka Devi J, Vijayashree N, Swetha VC, Archana R, Parathasarathy N \& Johanna R. Preliminary phytochemical screening and antimicrobial activity of Samanea saman. Journal of Medicinal Plants Research, 2008; 2(10):268-270. 